\title{
PEMANFAATAN LIMBAH KERTAS UNTUK TOPENG MALANGAN DAN WAYANG: IbM BAGI ANGGOTA POSDAYA EDELWEIS GAJAYANA DAN TERATAI PUTIH GAJAYANA
}

\author{
Fahmi Poernamawatie ${ }^{1 *}$, SBP Handhajani ${ }^{2}$, Endang Suswati ${ }^{3}$ \\ ${ }^{1}$ Program Studi Akuntansi, Fakultas Ekonomi dan Bisnis, Universitas Gajayana \\ Jl. Mertojoyo, Merjosari, Malang - Indonesia 65144 \\ ${ }_{2}^{2}$ Program Studi Sistem Informasi, Fakultas Teknik dan Informatika, Univesitas Gajayana \\ Jl. Mertojoyo, Merjosari, Malang - Indonesia 65144 \\ ${ }^{3}$ Program Studi Manajemen, Fakultas Ekonomi dan Bisnis, Universitas Gajayana \\ Jl. Mertojoyo, Merjosari, Malang - Indonesia 65144 \\ * Penulis korespondensi; Email: fahmipoerna@gmail.com
}

\begin{abstract}
Abstrak: Kegiatan pengabdian kepada masyarakat ini dimaksudkan untuk memberikan ketrampilan bagi anggota Posdaya Edelweis Gajayana dan Teratai Putih Gajayana melalui pemanfaatan limbah kertas untuk dijadikan Topeng Malangan dan Wayang Kulit sebagai salah satu upaya pendiversifikasian produk limbah kertas, sekaligus untuk menjaga lingkungan bersih dan pelestarian budaya lokal. Target dari kegiatan ini adalah mampu memproduksi Topeng Malangan dan Wayang Kulit limbah kertas, serta menggunakan media sosial sebagai salah satu cara pemasaran dan melakukan pencatatan keuangan sederhana. Metode pelaksanaan kegiatan ini meliputi pelatihan, pendampingan, dan memberikan bantuan peralatan yang berupa cetakan topeng dan pola wayang beserta peralatan pendukungnya. Luaran kegiatan ini berupa produk Topeng Malangan dan Wayang Kulit, modul/ panduan membuat topeng dan wayang, pemasaran online melalui media sosial, kewirausahaan, dan manajemen keuangan. Hasil pelaksanaan pelatihan dan pendampingan menunjukkan bahwa anggota Posdaya telah mampu membuat Topeng Malangan dan Wayang Kulit, serta dapat memanfaatkan media sosial (facebook dan weblog) sebagai sarana pemasaran online. Peserta pelatihan juga termotivasi untuk menjalankan usaha Topeng dan Wayang Kulit limbah kertas berdasarkan pesanan.
\end{abstract}

Kata kunci: Pelatihan; topeng malangan dan wayang; kewirausahaan; keuangan; pemasaran online

\begin{abstract}
This community service activity is intended to provide skills for members of Posdaya Edelweis Gajayana and Teratai Putih Gajayana through the utilization of waste paper to serve as Topeng Malangan and Wayang Kulit as one of the efforts to diversify waste paper products, as well as to maintain environment and preservation of local culture. The target of this activity is able to produce Mask Malangan and Wayang Kulit. Then, using social media as one way of marketing and make a simple record of financial. Methods of this activity include training, mentoring, and providing equipment in the form of mask prints and puppet patterns and their supporting equipment to implement result of training. The outcomes of this activity are Mask Malangan and Wayang Kulit products, modules/ guidelines for producing mask and wayang, online marketing through social media, entrepreneurship, and financial recording. The results of the training and mentoring show that Posdaya members have been able to use waste paper for creating Mask Malangan and Wayang Kulit. They can also utilize social media (facebook and weblog) as a tool of online marketing. Trainees are also motivated to run a business of producing and selling Mask Malangan and Wayang Kulit based on order.
\end{abstract}

Keywords: Training; Mask Malangan; Wayang; entrepreneurship; financial; online marketing.

\section{PENDAHULUAN}

Topeng dikenal sebagai salah satu atribut atau aksesoris yang sering dipakai oleh penari atau digunakan oleh seorang aktor. Topeng berkembang baik dari segi fungsi, karakter, ataupun teknik pembuatannya. Topeng pada awal kemunculannya mempunyai fungsi yang sakral. Topeng pertama terbuat dari emas. Harga emas tentu sangat mahal, maka topeng juga dibuat dari batu. Topeng dikenal dengan istilah puspo sariro (bunga dari hati yang paling dalam) dan merupakan simbol pemujaan Raja Gajayana terhadap arwah ayahandanya, Dewa Sima. Topeng merupakan bagian dari acara 
persembahyangan. (http://www.liputan6.com). Ini menunjukkan betapa berharganya keberadaan sebuah topeng pada masa itu.

Seiring perkembangan jaman, topeng pun beralih fungsi menjadi kesenian tari. Topeng digunakan menari untuk mendukung fleksibilitas penari. Untuk mempermudah riasan (make up) nya, para penari tinggal mengenakan topeng di mukanya. (Utomo. 2008). Oleh karena itu, diperlukan topeng yang bahan bakunya nyaman digunakan untuk menutup wajah penari tersebut.

Topeng yang berkembang di Malang disebut topeng Malangan, memiliki ciri khas tersendiri dibanding topeng yang berasal dari daerah lain. Tarian-tarian dengan menggunakan topeng, biasanya menuntut penari agar bisa membawakan karakter sesuai dengan karakter topeng yang dipakainya. Karakter topeng Malangan diwujudkan dalam bentuk hidung, mata, bibir atau mulut, dan warna topeng.

Perkembangan saat ini, topeng Malangan mulai digemari oleh para wisatawan yang datang ke Malang sebagai souvenir. Berbagai jenis topeng Malangan memiliki daya tarik sendiri. Hal ini juga disampaikan oleh Titik Andayati, pemilik galeri seni Kria Sigit Margono yang mengembangkan bisnis topeng Malangan di Malang. Topeng Raden Panji Asmara Bangun memiliki daya tarik yang berbeda dengan topeng Dewi Sekartaji dan topeng lainnya.

Topeng Malangan untuk souvenir dibuat dengan ukuran yang lebih kecil dari ukuran aslinya. Souvenir topeng dengan ukuran paling kecil yang berbahan fiber dijual dengan harga yang relatif mahal, yaitu kisaran Rp. 50.000 - Rp. 100.000 per biji, sedangkan yang berbahan kayu sekitar Rp. 250.000 per biji. Produk ini sering digunakan untuk cinderamata yang diberikan kepada para tamu undangan. Harga topeng Malangan akan tergantung model dan bahan serta budget pemesan.

Greeners.Co (2014) memberitakan bahwa pembuatan 1 (satu) topeng malangan berbahan kayu membutuhkan kayu panjang rata-rata 22 sentimeter dengan diameter 18 sentimeter. Kesalahan dalam mengukir, maka proses memotong kayu kembali diulang. Mahalnya pemrosesan topeng tersebut, maka ada inovasi dalam pembuatan topeng yang lebih ramah lingkungan, yaitu dengan memanfaatkan limbah kertas. Kesalahan pemrosesan dapat mengulang dengan tetap menggunakan olahan limbah kertas yang salah tersebut.

Jenis kesenian tradisional lainnya yang juga semakin digemari oleh bangsa asing dan mulai dipelajari oleh banyak orang adalah kesenian wayang kulit. Wayang kulit ini digunakan untuk menggambarkan tokoh pewayangan seperti Kresna, Werkudara, Gatotkaca, dan lain-lain. Selama ini, wayang kebanyakan berbahan kulit sapi, sehingga kerap disebut dengan wayang kulit. Wayang yang terbuat dari kulit sapi tentu harganya relatif mahal, yang menyebabkan para dalang pemula akan kesulitan untuk memilikinya.

Selain Topeng Malangan, Wayang Kulitpun dapat digunakan untuk souvenir. Namun, dengan adanya harga Topeng Malangan dan Wayang Kulit yang relatif mahal, maka diperlukan suatu inovasi terhadap pembuatan Topeng Malangan dan Wayang Kulit yang berbiaya relatif murah, namun tetap mempertahankan substansi keberadaan Topeng Malangan dan Wayang Kulit dengan memanfaatkan limbah kertas atau kertas bekas. Ramadhan (2015) menyatakan bahwa Pongky meruapakan salah satu pengrajin yang memanfatkan limbah kertas untuk topeng malangan sebagai langkah melestarikan budaya lokal khas Malang. Jika selama ini pembuatan topeng malangan berbahan kayu dan mahal, maka pilihannya adalah membuat topeng malangan berbahan dasar limbah kertas/koran. Keunggulan topeng berbahan kertas adalah murah, awet dan tidak mudah pecah. Topeng berbahan dasar kertas ini mulai banyak diminati masyarakat (Widianto dan Wibowo, 2015)

Pemanfaatan limbah kertas akan menjadi sebuah cara/solusi dalam pengelolaan lingkungan untuk menciptakan lingkungan yang bersih, sekaligus dapat menciptakan lapangan kerja untuk meningkatkan pendapatan keluarga, dan juga dalam upaya pelestarian budaya lokal.

Salah satu forum silaturahmi advokasi, komunikasi, informasi, edukasi, dan wadah koordinasi kegiatan penguatan fungsi-fungsi keluarga secara terpadu adalah Pos Pemberdayaan Keluarga (Posdaya). Tujuan membentuk Posdaya adalah menghidupkan semangat kebersamaan dan kegotongroyongan di masyarakat, dengan harapan anggota masyarakat mau berpartisifasi dan saling membantu dalam menangani masalah di bidang pendidikan, kesehatan, ekonomi, lingkungan dan agama.

Anggota Posdaya lebih diutamakan pada kelompok keluarga pra sejahtera dan sejahtera I. Upaya untuk memberdayakan anggota Posdaya dirasakan sangat perlu bagi Posdaya Edelweis Gajayana dan Teratai Putih Gajayana di Kelurahan Pandanwangi, Kecamatan Blimbing, Kota Malang. Berawal dari sebuah semangat yang sama dan kesamaan pemikiran di antara kedua Posdaya tersebut, pengurus Posdaya peduli terhadap kebersihan lingkungan dan perkembangan Sumber Daya Manusia. Akibat dari perkembangan zaman yang berdampak pada pergeseran budaya khususnya, di Kelurahan Pandanwangi perlu mendongkrak kreatifitas dan produktifitas kelompok kelompok keluarga pra sejahtera dan keluarga sejahtera I.

Posdaya Edelweis Gajayana dan Teratai Putih Gajayana memandang bahwa di wilayahnya banyak sampah yang dapat didaur ulang untuk menjadi barang yang bernilai jual dan berdaya guna. Pengurus kedua Posdaya telah berupaya 
untuk melaksanakan berbagai pelatihan dalam proses daur ulang sampah, seperti limbah plastik kresek. Saat ini kedua Posdaya mulai melangkah untuk mengembangkan upaya pada daur ulang limbah kertas dan/atau koran. Prospek usaha produk dari limbah ini sebenarnya sangat menjanjikan. Namun, bisnis produk dari limbah ini harus memiliki varietas produk yang banyak.

Sejauh ini, kedua Posdaya telah beberapa kali menerima pesanan dari masyarakat, seperti vas bunga dari limbah Koran, bunga dan dompet dari limbah tas kresek. Namun demikian, pelatihan yang telah dilakukan oleh ke dua Posdaya mitra IbM ini masih perlu ditingkatkan untuk menambah ragam produk yang bisa dihasilkannya. Untuk itu, pengurus kedua Posdaya melihat ada peluang yang besar dalam berbisnis Topeng Malangan dan Wayang Kulit dari limbah kertas yang dapat digunakan sebagai oleh-oleh khas Kota Malang dengan harga yang relatif murah tanpa mengurangi keindahan, kepentingan, dan kemanfaatannya.

Usia Posdaya yang relatif masih muda ini bukan merupakan hambatan bagi anggota Posdaya dalam menggeluti dunia bisnis, jika kedua Posdaya mitra memiliki target pengembangan usaha yang jelas. Permasalahan yang sering muncul sebagaimana halnya pada Posdaya di tempat lain, adalah keterampilan dan kemampuan berkreasi yang dimiliki oleh anggota Posdaya dirasa masih perlu ditingkatkan untuk melakukan pendiversifikasian produk dalam pengembangan bisnis yang lebih besar. Masalah lain yang muncul adalah jiwa wirausaha dari para anggota Posdaya yang juga perlu digerakkan dan ditingkatkan, selain aspek manajemen bisnis, dan lemahnya akses terhadap permodalan.
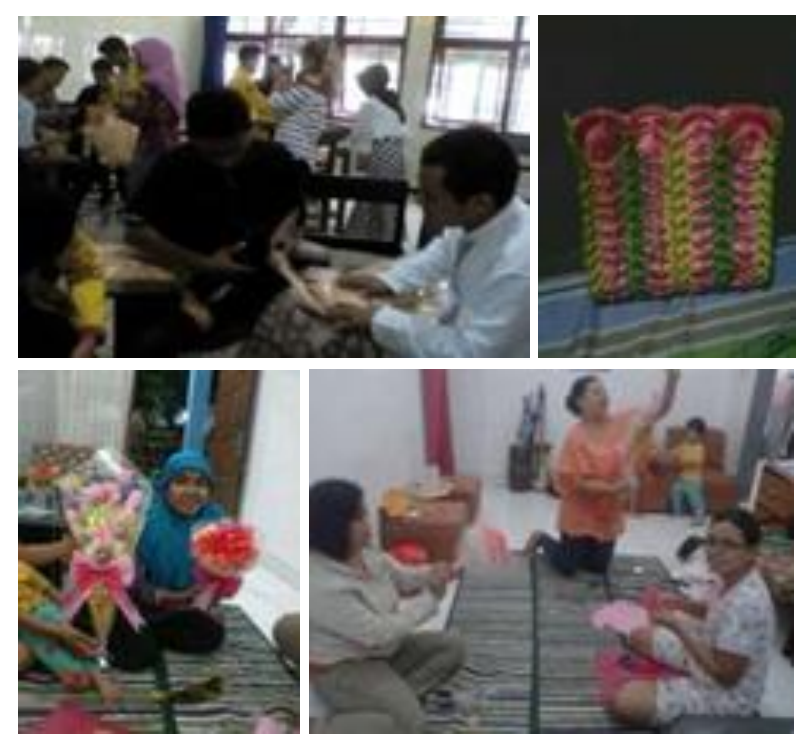

Gambar 1. suasana pelatihan bagi anggota Posdaya mitra dalam pembuatan produk-produk daur ulang tas kresek dan kertas dan/atau koran bekas.
Gambar 1 menunjukkan suasana pelatihan bagi anggota Posdaya mitra dalam pembuatan produk-produk daur ulang tas kresek dan kertas dan/ atau koran bekas menjadi buket bunga, bunga vas meja, rajut (bentel) tas kresek untuk dompet, vas dari koran bekas, tas belanja dari ring cup gelas minuman (teh gelas).

\section{PERMASALAHAN}

Iptek bagi Masyarakat (IbM) melibatkan 2 (dua) mitra Posdaya, yaitu Posdaya Edelweis Gajayana dan Posdaya Teratai Putih Gajayana. Kedua Posdaya tersebut merupakan Posdaya dampingan Universitas Gajayana. Anggota setiap Posdaya adalah seluruh warga dalam kelompok Pra Sejahtera dan Keluarga Sejahtera I, di lingkungan RW tempat Posdaya berada. Jumlah anggota Posdaya Edelweis sebanyak 22 (dua puluh dua) orang dan Posdaya Teratai Putih sebanyak 18 (delapan belas) orang. Keduanya terletak di Kelurahan Pandanwangi, Kecamatan Blimbing, Kota Malang.

Kedua mitra IbM adalah sebagai calon pelaku bisnis di pasar. Permasalahan yang dihadapi Posdaya dapat diidentifikasi sebagai berikut:

1. Kemampuan melakukan diversifikasi produk masih sangat lemah, sehingga pasar sering jenuh dengan ragam produk yang ada di Posdaya;

2. Administrasi pengelolaan usaha belum optimal dan catatan keuangan dilakukan masih sangat sederhana, masih jauh dalam memenuhi standar untuk UMKM. Catatan yang ada hanya catatan kas saja, itupun jika ada;

3. Pengelolaan produksi yang berorientasi pada pesanan bukan produksi masal. Hal ini menyebabkan lemahnya fungsi pemasaran, dan Posdaya belum memiliki strategi pemasaran yang tepat;

4. Masih kurangnya motivasi bisnis untuk pengembangan usaha. Hal ini berakibat kegiatan usaha berjalan secara stagnan tanpa ada upaya untuk pengembangan skala usaha secara masal dengan skala yang lebih besar.

Kegiatan IbM ini diharapkan bisa memberikan alternatif solusi bagi Posdaya dengan luaran yang ditargetkan dalam IbM ini adalah:

1. Cetakan dan produk Topeng Malangan limbah koran/kertas dengan 5 (lima) karakter, terdiri dari i). Panji Asmorobangun, ii). Dewi Sekartaji, iii). Dewi Ragilkuning, iv) Klonosewandhono, dan v). Bapang

2. Wayang Kulit dari limbah kertas, sebanyak 9 (Sembilan) yang terdiri dari 5 (lima) tokoh Pandawa (Yudhistira, Bima, Arjuna, Nakula dan Sadewa, serta 4 (empat) tokoh Punakawan (Semar, Gareng, Petruk, dan Bagong) 
3. Meningkatnya kemampuan pengurus Posdaya dalam berproduksi, kegiatan pemasaran produk, dan minat berwira usaha;

4. Meningkatnya kemampuan pengurus Posdaya dalam menyusun Laporan keuangan melalui kegiatan pelatihan dan pendampingan sehingga bisa meningkatkan akuntabilitas, transparansi dan kualitas manajemen keuangan Posdaya;

5. Publikasi ilmiah di Jurnal Nasional hingga tahap pengiriman untuk direview;

6. Publikasi pada media masa elektronik hingga tahap editing.

\section{METODE PELAKSANAAN}

Problem utama yang dihadapi Posdaya Edelweis dan Teratai Putih Gajayana kurangnya kemampuan/kompetensi anggota Posdaya untuk melakukan diversifikasi produk, pemasaran, lemahnya minat berwira usaha dan melakukan pembukuan sederhana. Pendekatan pelaksanaan kegiatan meliputi pelatihan, pemberian bantuan peralatan, dan pendampingan bagi ke dua mitra Posdaya. Pelaksanaan IbM melalui beberapa tahapan sebagai berikut:

1. Tahap perencanaan. Pelaksanaan IbM diawali dengan perencanaan yang matang. Kegiatan perencanaan diawali dengan kegiatan koordinasi dengan beberapa pihak. Koordinasi dimaksudkan untuk menjelaskan keberadaan program $\mathrm{IbM}$, maksud, tujuan dan rencana pelaksanaannya. Pelaksanaan koordinasi sebagai berikut: a). Koordinasi diantara Tim IbM pada tanggal 17 18 April 2017; b). Koordinasi antara Tim IbM dengan pengurus Posdaya dan Pengurus PKK Kelurahan Pandanwangi pada tanggal 19 - 21 April 2017.

2. Tahap Penyusunan Panduan dan Pembekalan. Tahapan ini dilakukan setelah mengadakan koordinasi dengan Posdaya dan Pengurus PKK Kelurahan Pandanwangi. Penyusunan panduan meliputi panduan pembuatan topeng dan wayang, modul pemasaran melalui media sosial, kewirausahaan, dan pembukuan sederhana. Keberadaan panduan diharapkan dapat membantu mitra untuk memahami melaksanakan kegiatan selama pelatihan. Penyusunan panduan mengacu pada informasi yang diperoleh dari hasil koordinasi dengan Pengurus Posdaya. Panduan dirancang sesuai dengan kebutuhan mitra kerja dengan format subtansi yang relatif sederhana, sehingga mudah dipahami. Pada tahap ini juga dilakukan pembekalan bagi Tim IbM. Kegiatan pembekalan dilaksanakan setelah panduan selesai dibuat. Tahapan ini dilaksanakan tanggal 22 - 4 Mei 2017.

3. Tahap Pelatihan. Kegiatan Pelatihan dilakukan 2 (dua) tahap. Pelatihan tahap pertama dimulai dengan memberikan pemahaman kepada anggota Posdaya sebagai calon wirausahawan, bahwa peluang bisnis itu dapat diciptakan dengan cara memanfaatkan limbah sampah, utamanya kertas bekas untuk Topeng Malangan dan Wayang, yang bernilai jual, berdaya guna, dan berbasis budaya lokal. Pelatihan tersebut dilakukan oleh dosen yang berkompeten di bidang kewirausahaan.

Pelatihan tahap ke dua dilaksanakan untuk materi pemasaran online dan pembukuan sederhana. Anggota posdaya dibekali cara menghitung biaya dan diperkenalkan berbagai cara pemasaran melalui dunia maya maupun konvensional. Pelatihan dilakukan oleh dosen anggota Tim IbM yang berkompeten di bidang Akuntansi dan Manajemen Keuangan serta Teknologi Informasi dan Pemasaran.

4. Tahap Pendampingan. Kegiatan pendampingan dilakukan Tim IbM untuk memantau pelaksanaan pengerjaan topeng dan wayang dari limbah kertas di rumah masing-masing anggota posdaya. Selain itu, di akhir pelaksanaan IbM, monitoring dan evaluasi internal juga dilakukan oleh Tim IbM dan reviewer internal. Tahapan ini bertujuan untuk memastikan bahwa para anggota posdaya telah trampil dalam membuat topeng dan wayang limbah kertas, hingga tidak mengalami kesulitan dalam proses produksi. Selain itu, Tim IbM juga memotivasi para anggota Posdaya dalam membangun jiwa wirausaha. Hal tersebut butuh ketekunan dan keuletan bagi calon entrepreneur.

5. Pencapaian hasil pelatihan secara optimal tidak terlepas dari dukungan dana dan keberadaan peralatan penunjang. Oleh karenanya, program IbM juga memberikan bantuan berupa cetakan topeng dan pola wayang limbah kertas serta peralatan pendukung bagi anggota Posdaya yang ikut aktif dalam pelatihan dan pendampingan. Bantuan ini dirasa penting untuk keberlanjutan upaya mitra untuk bisa mengawali bisnis pemanfatan limbah kertas berupa topeng dan wayang.

\section{HASIL PELAKSANAAN}

\section{Profil Posdaya Mitra}

Posdaya Edelweis Gajayana dan Teratai Putih Gajayana di Kelurahan Pandanwangi, Kecamatan Blimbing, Kota Malang adalah Posdaya dampingan Universitas Gajayana Malang. Pengurus Posdaya ini memfasilitasi kelompok keluarga pra sejahtera dan keluarga sejahtera I, yang tidak memiliki rutinitas pekerjaan, untuk belajar bersama, dengan berorientasi pada dunia kerja dan dunia usaha sehingga menjadi manusia yang produktif, kreatif dan inovatif. Kedua Posdaya ini, didirikan pada tanggal 20 Agustus 2015 dengan didasarkan pada Keputusan Kepala Kelurahan Pandanwangi.

Koordinator Posdaya Edelweis Gajayana adalah Ibu Dartik, sedangkan Koordinator Posdaya Teratai Putih Gajayana adalah Ibu Rahayu Widi 
Lestari. Anggota kedua Posdaya tersebut masingmasing sebanyak 22 (dua puluh dua) orang untuk Posdaya Edelweis dan 18 (delapan belas) orang untuk Posdaya Teratai Putih. Namun dari sejumlah anggota tersebut, yang aktif berkegiatan dalam Posdaya sebanyak 20 (dua puluh) orang.

Anggota kedua Posdaya mitra memiliki minat dan tekad yang besar untuk bisa membantu ekonomi keluarga dengan berwirausaha. Pada saat ini, di lingkungan rumah para anggota Posdaya tersedia limbah kertas yang masih belum dimanfaatkan secara optimal. Sejalan dengan hasrat para anggota Posdaya tersebut, Pemerintah Kelurahan Pandanwangi memang sedang menggalakkan program peduli lingkungan bersih dan telah melaksanakan berbagai pelatihan dalam pemanfaatan limbah. Dengan demikian, keberadaan program $\mathrm{IbM}$ ini sangat membantu pemerintah, juga masyarakat setempat.

\section{DESKRIPSI PELAKSANAAN}

Pelaksanaan pelatihan telah dilakukan oleh Tim IbM. Berdasarkan hasil diskusi dan kesepakatan antara Tim IbM dengan Posdaya, maka pelatihan telah dilakukan sebanyak 2 (dua) tahap. Pelatihan tahap pertama dilaksanakan tanggal $12-13 \mathrm{Mei}$ 2017. Pembekalan dilakukan oleh dosen yang berkompeten di bidang kewirausahaan. Hasil dari pelatihan ini adalah anggota Posdaya mitra memiliki pemahaman adanya peluang bisnis pemanfaatan limbah kertas, untuk Topeng Malangan dan Wayang. Peserta pelatihan juga termotivasi untuk berwirausaha dalam membuat topeng dan wayang limbah kertas, karena produk ini selain berbiaya murah juga berbasis budaya lokal.

Materi lain dari pelatihan pertama adalah pembuatan Topeng Malangan dan Wayang Punokawan dari limbah kertas. Hasil pelatihan ini adalah anggota Posdaya mampu membuat cetakan topeng beserta topeng ukuran kepala manusia dan pola wayang beserta wayang punokawan.
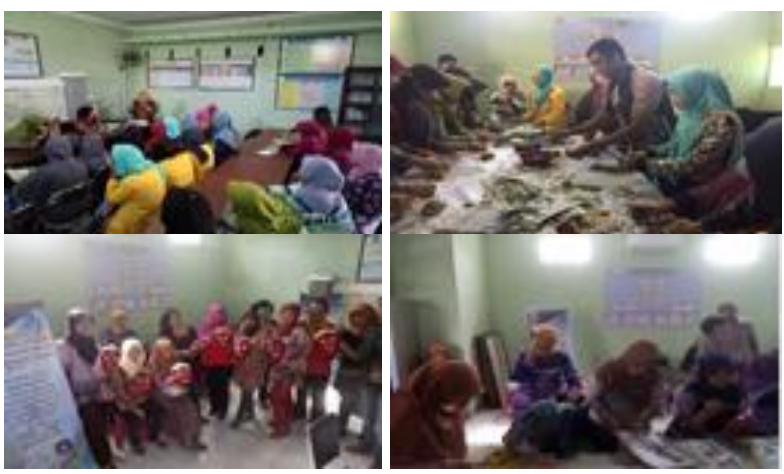

Gambar 2. Pelatihan Tahap Pertama

Hasil pembuatan topeng pada pelatihan pertama masih banyak kekurangannya. Oleh karena itu, Tim IbM membekali anggota Posdaya dengan bahan pembuatan topeng dan wayang serta cetakannya. Anggota Posdaya harus mengerjakan di rumahnya masing-masing, mulai dari pembuatan pola, cetakan, hingga produk akhir baik untuk topeng maupun wayang. Pendampingan dilakukan Tim IbM untuk memantau pelaksanaan pengerjaan topeng dan wayang dari limbah kertas di rumah masing-masing anggota posdaya. Kegiatan pendampingan ini bertujuan untuk memastikan bahwa para anggota posdaya semakin trampil dalam membuat topeng dan wayang limbah kertas, hingga tidak mengalami kesulitan dalam proses produksi.

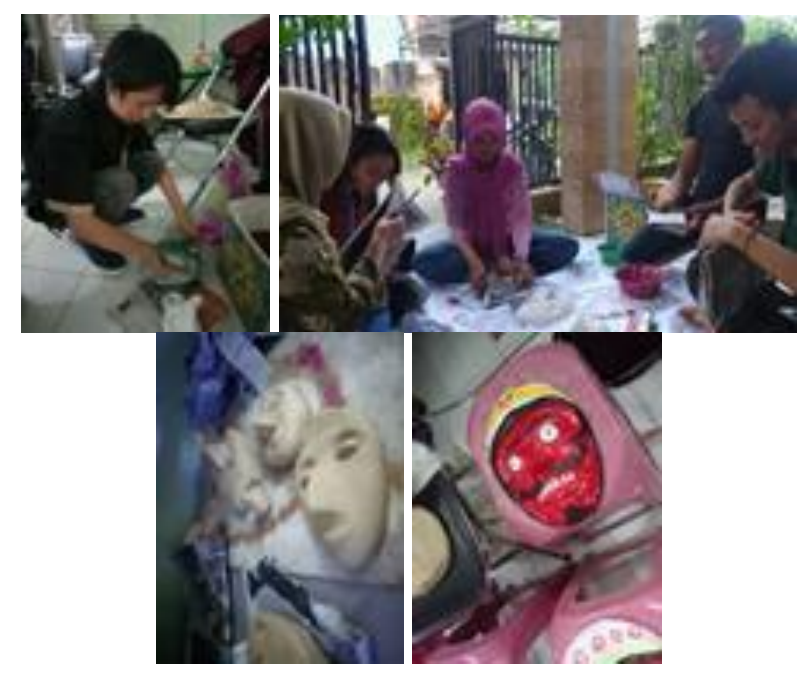

Gambar 3. Pendampingan

Selain itu, Tim IbM juga melakukan komunikasi dengan anggota Posdaya melalui telpon atau SMS atau WA. Kegiatan pendampingan lapangan tahap pertama dilaksanakan tanggal 17-20 Mei 2017, selebihnya melalui alat komunikasi sesuai kesepakatan bersama.

Pelatihan ke dua dilaksanakan untuk pembekalan materi pemasaran online dan pembukuan sederhana. Anggota posdaya dibekali cara menghitung biaya dan diperkenalkan berbagai cara pemasaran melalui dunia maya maupun konvensional. Pelatihan dilakukan oleh dosen anggota Tim IbM yang berkompeten di bidang Akuntansi dan Manajemen Keuangan serta Teknologi Informasi dan Pemasaran. Pelaksanaan pelatihan dibantu oleh para mahasiswa Program Studi Akuntansi, Manajemen dan Sistem Informasi.

Pelatihan tahap ini juga diisi dengan membuat topeng ukuran kecil yang dapat digunakan untuk cinderamata/ souvenir, yang meliputi: cetakan dan produk topeng malangan dari limbah kertas dengan lima karakter yaitu: Panji Asmorobangun, Dewi Sekartaji, Dewi Ragilkuning, Klonosewandhono, dan Bapang.

Hasil pelatihan tahap ke dua ini adalah anggota Posdaya sebagai calon wirausaha bisa menghasilkan produk topeng ukuran kecil dengan mempertahankan konsistensi dalam menjaga kualitas 
hasil produksi. Selain itu, peserta bisa melakukan pemasaran melaui blog dan Instagram. Peserta juga bisa membuat pembukuan sederhana dan menghitung biaya produksi untuk dasar penetapan harga jual, dan juga semakin familiar dengan permasalahan manajemen bisnis. Peserta pelatihan pada tahap ke dua mulai berkurang. Mereka yang antusias dan kelihatan tangguh serta ulet melanjutkan untuk mengikuti kegiatan IbM. Pelatihan tahap ke dua dilaksanakan tanggal 8 Agustus 2017.

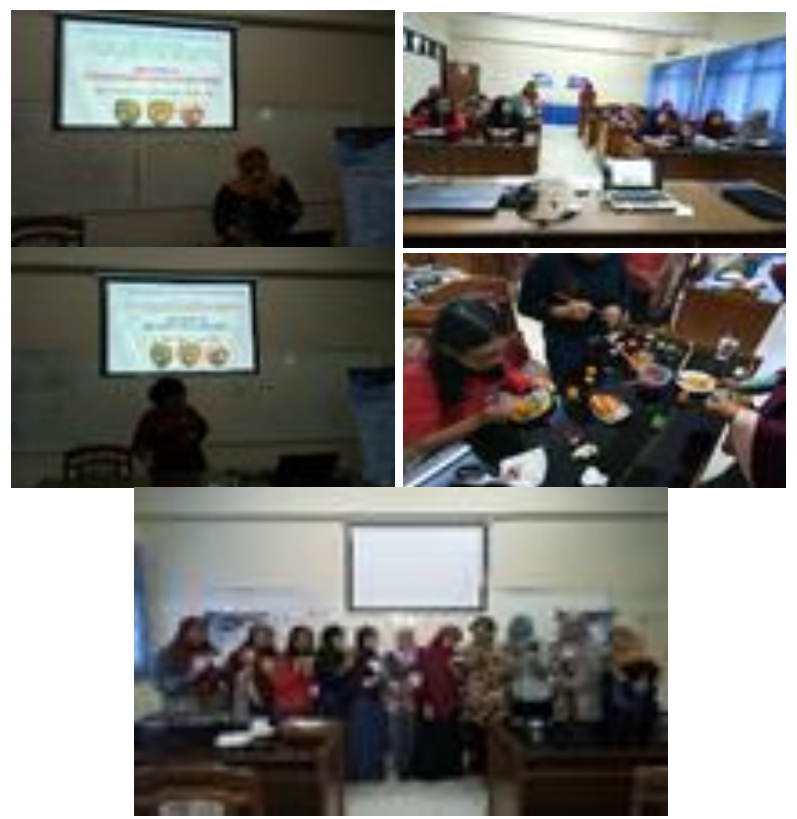

Gambar 4. Pelatihan Akuntansi/Keuangan, Pemasaran Online, dan Topeng Kecil

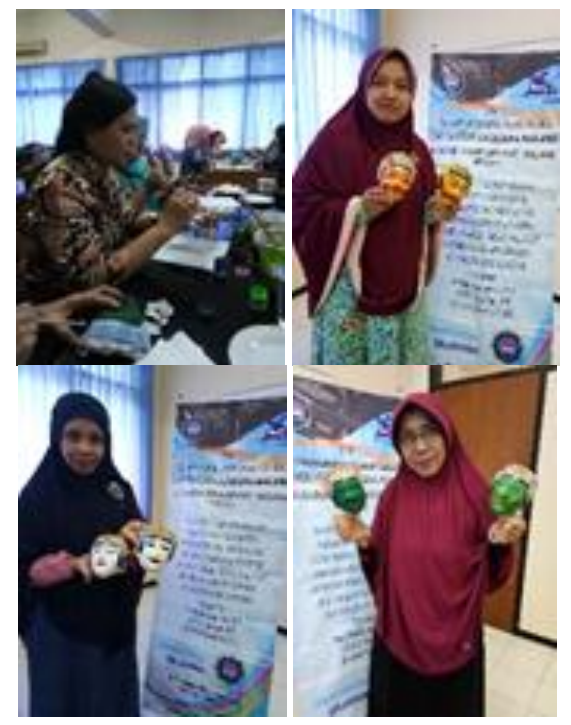

Gambar 5. Pendampingan

Tahap akhir dari kegiatan IbM ini adalah pendampingan ke tiga. Tim IbM mendampingi dalam proses produksi, melaksanakan pembukuan dan pemasaran produk topeng dan wayang limbah kertas. Tahap ini sekaligus juga melaksanakan monitoring dan evaluasi tahap akhir. Kegiatan tersebut dilaksanakan hingga akhir bulan September 2017.

Anggota Posdaya yang sangat antusias untuk mengikuti pelatihan membuat jenis produk baru, memiliki komitmen untuk memulai berwira usaha dan mengembangkan kreasi sendiri. Hasil pelatihan yang telah diperoleh mulai diaplikasikan dalam upayanya berbisnis, meski masih berbasis pesanan.

Pada saat kegiatan pendampingan, peserta (per kelompok) diberi tugas untuk membuat cetakan topeng, punakawan hingga produk jadi. Untuk memotivasi peserta, hasilnya dilombakan untuk dicari hasil yang terbaik.

\section{Produksi Topeng dan Wayang Limbah}

Secara keseluruhan, hasil dari pelatihan dan pendampingan yang telah diperoleh anggota Posdaya baik dari aspek produksi memang masih harus selalu disempurnakan dengan cara banyak berlatih. Untuk menjadi wirausaha yang tangguh masih diperlukan latihan, keuletan, dan kesungguhan dari para anggota Posdaya, terutama pada kemampuan berproduksi. Hal tersebut Nampak dari hasil monitoring dan evaluasi (monev).

Perkembangan hasil produksi yang dilakukan oleh anggota Posdaya mitra digolongkan menjadi 3 (tiga) kategori, yaitu Layak Jual (LJ), Perlu Penghalusan (PH), Tidak Layak Jual (TLJ). Tim IbM minta bantuan 3 (tiga) orang independen untuk menilai hasil produksi anggota Posdaya. Hasil penilaian pihak independen sebagaimana dalam Tabel 1.

Tabel 1. Produksi Topeng Malangan dan Wayang Limbah Kertas

\begin{tabular}{ccccc}
\hline \multirow{2}{*}{ Kategori } & \multicolumn{2}{c}{$\begin{array}{c}\text { Pembuat Topeng } \\
\text { Malangan }\end{array}$} & \multicolumn{2}{c}{ Pembuat Wayang } \\
\cline { 2 - 5 } & Orang & \% & Orang & \% \\
\hline LJ & 5 & 50 & 2 & 50 \\
PH & 3 & 30 & 2 & 50 \\
TLJ & 2 & 20 & - & - \\
Jumlah & 10 & 100 & 4 & 100 \\
\hline
\end{tabular}

Tabel 1 menjelaskan bahwa dari 10 (sepuluh) orang anggota Posdaya yang aktif, sebanyak 5 (lima) orang atau $50 \%$ nya sudah mampu membuat Topeng Malangan ukuran kecil untuk souvenir. Anggota Posdaya yang gagal membuat topeng sebanyak 2 (dua) orang atau $20 \%$ nya, sedangkan yang masih memerlukan latihan secara intensif sebanyak 3 (tiga) orang atau $30 \%$ nya.

Hasil monev juga menunjukkan bahwa produksi Topeng Malangan ukuran kecil dikemas dalam pigura, kotak mika dan sebagai pemanis tempat pensil acrylic. Posdaya mitra juga telah menerima pesanan pada minggu ke dua bulan September 2017 berupa 25 (dua puluh) unit topeng kecil untuk pemanis tempat pensil acrylic dan 2 (dua) souvenir dalam pigura. 


\section{Akuntansi dan Keuangan}

Proses pencatatan atau pembukuan memerlukan pemahaman yang baik tentang akuntansi dan keuangan, ketelitian, dan ketelatenan. Meski masih agak susah untuk mengubah pola pikir dari "semau gue" menjadi disiplin dalam catat mencatat, namun anggota Posdaya mitra yang memiliki komitmen tinggi dalam pengembangan usaha sudah mulai mengimplementasikannya. Tabel 2 menunjukkan perkembangan praktik pembukuan sederhana yang telah dilakukan oleh anggota Posdaya. Meski pencatatannya masih sangat sederhana, tetapi anggota Posdaya sudah mulai memiliki buku kas harian, nota penjualan, daftar tagihan dan utang. Kriteria penilaian pemahaman anggota Posdaya terhadap bidang akuntansi dan keuangan dilihat dari ketersediaan jenis catatan yang ada di setiap anggota.

Tabel 2. Jenis Catatan Akuntansi

\begin{tabular}{lccccc}
\hline \multirow{2}{*}{$\begin{array}{l}\text { Jenis Catatan } \\
\text { Akuntansi }\end{array}$} & \multicolumn{3}{c}{ Jumlah Pemilik Catatan } & \\
\cline { 2 - 5 } & \multicolumn{2}{c}{ Ada Catatan } & \multicolumn{2}{c}{$\begin{array}{c}\text { Tidak Ada } \\
\text { Catatan }\end{array}$} & Jumlah \\
\cline { 2 - 5 } & Orang & $\%$ & Orang & $\%$ & \\
\hline Buku Kas Harian & 10 & 100 & - & - & 10 \\
Nota Penjualan & 10 & 100 & - & - & 10 \\
$\begin{array}{l}\text { Buku Utang/ } \\
\text { Piutang }\end{array}$ & 4 & 40 & 6 & 60 & 10 \\
$\begin{array}{l}\text { Lain-lain (Kartu } \\
\text { Persediaan) }\end{array}$ & 2 & 20 & 8 & 80 & 10 \\
\hline
\end{tabular}

Praktik lainnya tentang akuntansi dan keuangan yang dilakukan oleh anggota Posdaya adalah penetapan biaya produksi dan harga jual produk. Biaya produksi sebuah Topeng Malangan akan terdiri dari bahan baku, upah tenaga kerja dan biaya produksi lainnya. Penetapan harga jual secara rata-rata ditetapkan 140\% - 150\% dari biaya produksi masing-masing produk sebagaimana dalam Tabel 3.

Materi akuntansi dan keuangan merupakan materi yang sulit untuk dipahami bagi mitra $\mathrm{IbM}$. Namun demikian, mitra IbM dapat merespon dengan baik untuk dipraktikkan. Anggota Posdaya sadar, akuntansi dan keuangan bukanlah hal yang mudah, namun akuntansi dan keuangan memang sangat diperlukan dalam pengembangan sebuah usaha. Upaya Tim IbM untuk menyadarkan para anggota Posdaya kerapkali mendapat tantangan, karena selama ini para anggota Posdaya sudah terbiasa menerapkan pengelolaan usaha secara tradisional, yang telah terbukti bahwa usahanya tetap berjalan dan bisa berkembang. Oleh karena itu, dalam setiap pendampingan dengan kunjungan lapangan ataupun melalui kontak telepon, tim IbM secara terus menerus berusaha memberikan arahan atas materi yang belum dipahami.
Tabel 3. Penetapan Harga Jual produk

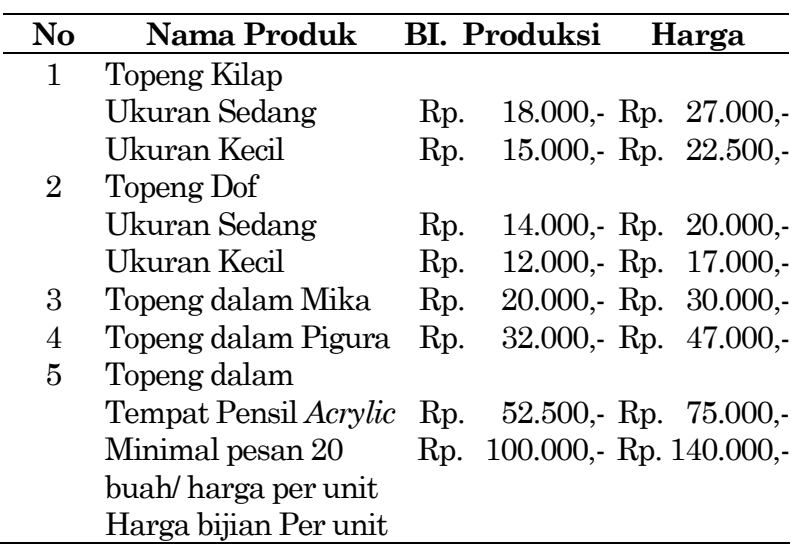

\section{Pemasaran online}

Pemasaran adalah kegiatan manajemen yang memerlukan keuletan hingga bisa mendapatkan calon pelanggan menjadi tertarik dengan suatu produk, hingga mengambil keputusan membelinya. Saat ini, banyak cara untuk memasarkan produk, mulai dari yang konvensional (misal dari rumah ke rumah) hingga melalui pemanfaatan teknologi informasi. Tim IbM menanamkan pemikiran yang kuat dalam hal kualitas layanan, kecepatan dan ketepatan waktu untuk melayani kebutuhan pelanggan tetap menjadi prioritas utama dalam menyokong keberhasilan usaha.

Kualitas layanan memiliki peran yang penting dalam menggungah dan merangkul konsumen untuk mengambil keputusan dalam membeli produk maupun untuk melakukan pembelian ulang. Jika perusahaan mampu memberikan layanan yang baik dan berkualitas, maka hal ini akan memberikan efek ganda, yakni di satu sisi citra bisnis akan baik, dan konsumen akan dengan senang hati untuk memberikan rekomendasi kepada calon konsumen yang lain untuk mau membeli produk tersebut.

Program IbM mengenalkan kepada mitra untuk dapat memanfaatkan teknologi informasi melalui media sosial untuk digunakan memasarkan produk Topeng Malangan dan Wayang Limbah Kertas. Hal ini dimaksudkan untuk membantu anggota Posdaya yang hanya memiliki sedikit ruang gerak, bisa lebih leluasa dalam kegiatan pemasaran. Anggota Posdaya tanpa harus memerlukan tambahan waktu untuk meninggalkan rumah dalam memasarkan produk topeng dan wayang buatannya. Sehingga fleksibilitas dalam kegiatan memproduksi dan memasarkan masih tetap terjaga, meski tidak juga meninggalkan caracara pemasaran konvensional, dengan tetap menjalin tali silaturahim dengan calon pelanggan.

Hasil monev terhadap mitra kerja IbM menunjukkan bahwa cara memasarkan produk topeng dan wayang limbah sudah dicoba melalui media social, yaitu dengan blog, instagram, dan wa. 
Tim IbM juga melihat bahwa anggota Posdaya juga menyadari bahwa keberadaan konsumen akan sangat tergantug pada cara pemasaran, layanan yang baik dan berkualitas, kecepatan dan ketepatan dalam menghandel konsumen dan pesanan, serta keberadaan konsumen menjadi pusat perhatian karena konsumen akan sangat menentukan kelangsungan usaha.

Tabel 4 menunjukkan cara pemasaran baik secara konvensional maupun melalui media sosial yang digunakan oleh anggota Posdaya.

Tabel 4. Cara Pemasaran

\begin{tabular}{lcc}
\hline \multirow{2}{*}{ Jenis Pemasaran } & \multicolumn{2}{c}{ Jumlah Pengguna } \\
\cline { 2 - 3 } & Orang & \% \\
\hline WhatsApp (WA) & 10 & 100 \\
Blog & 3 & 30 \\
Instagram & 3 & 30 \\
Konvensional & 10 & 100 \\
\hline
\end{tabular}

\section{PEMBAHASAN}

Pengabdian kepada Masyarakat yang didanai oleh Kemenristekdikti dengan skema Ipteks bagi Masyarakat (IbM) bagi anggota Posdaya Edelweis Gajayana dan Teratai Putih Gajayana diharapkan dapat meningkatkan ketrampilan mitra dalam berproduksi, memasarkan dan mengadministrasikannya, utamanya pada kegiatan produksi Topeng Malangan dan Wayang Limbah Kertas. Hasil kegiatan IbM akan dicapai dengan optimal melalui berbagai rangkaian kegiatan yang dirancang secara sistematis, yang meliputi metode pelaksanaan, materi yang disampaiakan, cara pelatihan dan pendampingannya. Semua kegiatan tersebut tentu sudah melalui koordinasi dengan mitra dan pelaksanaannya menyesuaikan bersifat kondisional dan situasional, selaras dengan kebutuhan, kemampuan, serta kemauan mitra.

Pelatihan tahap pertama diisi materi kewirausahaan, yang meliputi cara meningkatkan pendapatan keluarga melalui wirausaha, berbagai peluang bisnis produk limbah yang berdaya guna dan berdaya saing. Materi lain yang diberikan adalah menciptakan lingkungan bersih dengan memanfaatkan limbah untuk produk berbasis budaya lokal melalui pelatihan pembuatan Topeng Malangan dan Wayang Limbah Kertas. Materi ini dipandang penting untuk membuka wawasan mitra dalam berwira usaha dengan memanfaatkan barang bekas/limbah yang ada di sekitarnya. Materi pelatihan diberikan oleh anggota Tim IbM yang memiliki kompetensi di bidang kewirausahaan dan proses pengolahan limbah kertas untuk topeng dan wayang.

Respon positip diberikan oleh mitra terhadap materi tahap awal. Mitra bersungguh-sungguh mengikuti tahapan kegiatan hingga akhir. Mitra secara aktif melakukan kegiatan sesuai dengan instruksi yang diberikan. Suasana pelatihan yang kondusif dapat membangun komunikasi dua arah yang baik. Kegiatan pelatihan yang dapat diserap dengan baik oleh para mitra memudahkan kegiatan $\mathrm{IbM}$ selanjutnya dalam bentuk pendampingan.

Secara normatif, Dale (2003) menyatakan aktivitas pelatihan seyogyanya dapat mengubah sistem berpikir dan perilaku individu peserta latihan. Mondy (2008: 210) juga menyatakan bahwa pelatihan akan memberikan pengetahuan dan ketrampilan yang dibutuhkan oleh pembelajar agar dapat melaksanakan pekerjaannya. Pelatihan dimaksudkan untuk menfasilitasi pembelajar dalam mempelajari tingkah laku yang berhubungan dengan pekerjaannya yang bertujuan untuk meningkatkan kinerja. (Bartol dalam Wiludjeng, 2007: 131)

Untuk menunjang keberhasilan program IbM, tim IbM telah menyiapkan beberapa panduan antara lain panduan pembuatan topeng dan wayang limbah kertas, pemasaran melalui media social, dan akuntansi/ keuangan dalam pembukuan sederhana.

Pelaksanaan program IbM selain pelatihan, juga melalui pendampingan serta monitoring dan evaluasi terhadap hasil pelatihan. Kedua kegiatan ini dilakukan dengan berkunjung ke lokasi dan memberikan advis yang diperlukan mitra. Hal ini dimaksudkan untuk memantau secara langsung terhadap perkembangan kemampuan mitra serta mempersiapkan dengan sungguh-sungguh bahwa mitra telah siap melakukan usaha di bidang Topeng Malangan dan Wayang Limbah Kertas. Program IbM juga memberikan bantuan peralatan berupa cetakan Topeng Malangan dan pola Wayang serta beberapa bahan yang diperlukan dan peralatan penunjang kepada Mitra.

Upaya pelaksanaan IbM melalui pelatihan, pendampingan dan pemberian bantuan bahan dan peralatan produktif kepada mitra diharapkan dapat mengoptimalkan para anggota Posdaya untuk memulai usaha, sehingga usaha mereka ini dapat berjalan dengan lebih baik. Usaha yang dikelola dengan proses manajemen yang baik dan profesional akan mampu membuat suatu bisnis bertahan hidup, dan bahkan berkembang lebih maju. (Daft, 2006)

\section{KESIMPULAN DAN SARAN}

\section{Kesimpulan}

Kegiatan pengabdian kepada masyarakat skema IbM bagi anggota Posdaya Edelwis Gajayana dan Teratai Putih Gajayana telah dilaksanakan dengan lancar. Hasil pelaksanaan program IbM tersebut dapat disimpulkan sebagai berikut: 
1. Program IbM sangat diperlukan bagi anggota Posdaya. Hal ini dibuktikan dengan adanya respon yang sangat baik dan antusiasme anggota Posdaya dalam mengikuti serangkaian kegiatan IbM dari awal hingga akhir;

2. Keberadaan program IbM membantu mitra dalam peningkatan minat berwirausaha, ketrampilan berproduksi, memasarkan melalui media sosial berbasis teknologi informasi, dan pembukuan sederhana yang dilaksanakan melalui kegiatan pelatihan, pendampingan dan adanya bantuan bahan dan peralatan dari pemerintah;

3. Pemanfaatan limbah koran dan kertas untuk diolah menjadi berbagai produk budaya yang bernilai guna dan bernilai jual, merupakan salah satu upaya menciptakan kreasi baru dalam produksi Topeng Malangan dan Wayang dengan harga yang relatif murah. Jika hal ini ditekuni, maka akan bermanfaat bagi Anggota Posdaya Edelweis Gajayana dan Tearatai Putih Gajayana untuk meningkatkan daya beli mereka dalam pemenuhan kebutuhan sehari-hari;

4. Peningkatan ketrampilan dan pemahaman mitra terhadap pemanfaatan limbah koran dan kertas dapat menumbuhkan minat mitra untuk mengawali usaha melalui pemanfataan limbah kertas tersebut, baik secara mandiri maupun berkelompok;

5. Implementasi hasil pelatihan dan pendampingan dalam memanfaatkan bantuan bahan dan peralatan telah dilaksanakan selama proses pendampingan hingga berakhir kegiatan IbM. Hal ini dibuktikan dengan adanya penyelesaian pesanan konsumen atas produk Topeng Malangan Limbah Kertas untuk souvenir;

6. Peningkatan kemampuan di bidang pemasaran dengan menggunakan media sosial berbasis teknologi informasi telah dibuktikan oleh anggota Posdaya mitra dengan memanfaatkan blog, Instagram, dan wa sebagai sarana memasarkan produknya;

7. Peningkatan pengetahuan serta ketrampilan bidang akuntansi/keuangan ditunjukkan dari adanya kemampuan mitra melakukan perhitungan biaya produksi sebagai dasar penetapan harga jual, serta adanya beberapa catatan pembukuan sederhana.

\section{Saran}

Anggota Posdaya Edelweis Gajayana dan Teratai Putih Gajayana pasti memiliki mimpi untuk melanjutkan usaha Topeng Malangan dan Wayang Limbah Kertas bisa berkembang dengan baik. Untuk dapat terwujudnya impian tersebut, maka Tim IbM memberikan saran sebagai berikut:
1. Anggota Posdaya seharusnya selalu berkomunikasi dengan Tim IbM demi lancarnya kegiatan produksi, pemasaran, dan administrasi usaha, sehingga kegiatan pendampingan bisa dilaksanakan secara kontinyu dan rutin, hingga mitra siap mandiri;

2. Sebagai tindak lanjut program IbM, upaya pendiversifikasi produk limbah kertas dalam bentuk Topeng Malangan dan Wayang serta produk lainnya tetap harus dilakukan secara kontinyu. Hal ini dimaksudkan untuk menjaga keberlangsungan usaha;

3. Pembinaan lanjutan pasca program $\mathrm{IbM}$, Anggota Posdaya mitra harus memperoleh support dari Pemerintah Kelurahan Pandanwangi dan/ atau Pemerintah Kota Malang untuk dapat melakukan pemasaran secara intensif, baik pemasaran online maupun konvensional untuk membumikan produk Topeng Malangan dan Wayang limbah kertas sebagai produk lokal yang berkualitas dengan harga yang terjangkau.

4. Kajian awal diperlukan untuk memastikan bahwa usaha Topeng Malangan dan Wayang Limbah Kertas ini bisa menjadi usaha yang marketable untuk menyiapkan souvenir khas Kota Malang.

\section{UCAPAN TERIMAKASIH}

Ucapkan terima kasih kepada beberapa pihak antara lain:

a. Kementerian Riset, Teknologi, dan Pendidikan Tinggi atas program Hibah Program Pengabdian Kepada Masyarakat bagi perguruan Tinggi.

b. Lembaga Penelitian dan Pengabdian Kepada Masyarakat Universitas Gajayana Malang Banyuwangi yang telah bekerjasama dalam pelaksanaan kegiatan IbM ini;

c. Segenap tim IbM yang telah bekerjasama dengan baik.

d. Kelompok Posdaya Edelweis dan Teratai Putih Gajayana yang telah menunjukkan komitmen kuat dalam menjalankan usaha topeng dan menerima berbagai masukan positif.

\section{DAFTAR PUSTAKA}

Daft, R. L. (2006). Manajemen. Edisi 6. Jakarta: Salemba Empat

Dale, M. 2003. Developing Management Skill. (Terjemahan). Jakarta: Gramedia

Greeners.Co. 2014. Tak Perlu Tebang Kayu untuk Membuat Topeng Malangan. http://www. greeners.co/ide-inovasi/tak-perlu-tebang-kayuuntuk-membuat-topeng- malangan/

Mondy, R. Wayne. 2008. Manajemen Sumber Daya Manusia. Terj. Edisi kesepuluh jilid I bekerjasama dengan Penerbit Erlangga. Jakarta: Erlangga. 
Ramadhan, Lucky Aditya. 2015. Pongky Ciptakan Topeng Malangan dari Limbah Kertas (http:// beritajatim.com/gaya_hidup/252422/pongky_ ciptakan_topeng_malangan_dari_limbah_kerta s.html)

Utomo, Paring Priyo. 2008. Topeng Malangan Simbol Pertarungan Berbagai Identitas. http:// www.averroes.or.id/topeng-malangan-simbolpertarungan-berbagai-identitas.html
Wibowo, Eko Ari. 2015. Topeng Limbah Kertas Kini Diburu Pecinta Seni di Malang, https://nasional. tempo.co/read/720222/topeng-limbahkertas-kini-diburu-pecinta-seni-di-malang

Widianto, Eko dan Eko Ari Wibowo. 2015. Topeng Limbah Kertas Kini Diburu Pecinta Seni Di Malang

https://m.tempo.co/read/news/2015/11/ 19/058720222/topeng-limbah-kertas-kinidiburu-pencinta-seni-di-malang

Wiludjeng, Sri. 2007. Pengantar Manajemen. Yogyakarta: Graha Ilmu. 